\title{
Hypothyroid offspring replacement with euthyroid wet nurses during lactation improves thyroid programming without modifying metabolic programming
}

Jorge Tapia-Martínez', 2, Margarita Franco-Colín', Rocio Ortiz-Butron², Marisol Pineda-Reynoso ${ }^{3}$, Edgar Cano-Europa'

\begin{abstract}
Objective: Determine the milk quality effect during lactation on the metabolic and thyroid programming of hypothyroid offspring. Materials and methods: Ten-week-old female Wistar rats were divided into two groups: euthyroid and thyroidectomy-caused hypothyroidism. The rats were matted and, one day after birth, the pups were divided into three groups: euthyroid offspring (EO), hypothyroid offspring $(\mathrm{HO})$ and hypothyroid with a euthyroid replacement wet nurse (HRO). During lactation, the milk quality and offspring body length were evaluated. The body weight and energy intake were determined on a weekly basis, as well as the metabolic profile at the prepubertal (P3536) and postpubertal (P55-56) ages. At P56, the animals were sacrificed, the adipose tissues were weighed and the thyroid glands were dissected for histological processing. Results: The milk of the hypothyroid wet nurse decreases proteins (16-26\%), lipids (22-29\%) and lactate (22-37\%) with respect to euthyroid. The $\mathrm{HO}$ has a lower body weight gain $(23-33 \%)$, length (11-13\%) and energy intake (15$21 \%)$. In addition, $\mathrm{HO}$ presents impaired fasting glucose and dyslipidemia, as well as a reduction in seric thyroid hormone (18-34\%), adipose reserves (26-68\%) and thyroid gland weight (25-34\%). The HO present thyroid gland cytoarchitecture alteration. The HRO develop the same metabolic alterations as the HO. However, the thyroid gland dysfunction was partially prevented because the HRO improved under about $10 \%$ of the serum thyroid hormone concentration, the thyroid gland weight although histological glandular changes presented. Conclusions: The replacement of hypothyroid offspring with a euthyroid wet nurse during lactation can improve the thyroid programming without modifying metabolic programming. Arch Endocrinol Metab. 2019;63(3):199-207
\end{abstract}

Keywords

Congenital hypothyroidism; lactation; metabolic programming; thyroid programming; thyroid gland
1 Departamento de Fisiología, Escuela Nacional de Ciencias Biológicas. Instituto Politécnico Nacional, Ciudad de México, México 2 Departamento de Fisiología, Escuela Nacional de Ciencias Biológicas. Instituto Politécnico Nacional, Ciudad de México, México ${ }^{3}$ Academía de Histología, Departamento de Formación Básica Disciplinaria, Escuela Superior de Medicina. Instituto Politécnico Nacional, Ciudad de México, México

Correspondence to:

Edgar Cano-Europa

edgarcanoeuropa@yahoo.com.mx

Received on Feb/10/2017 Accepted on Mar/10/2017

DOI: $10.20945 / 2359-3997000000132$

\section{INTRODUCTION}

I $n$ recent years, several observations have assumed that metabolic diseases in adulthood emerge in utero or during lactation as a change result in the organs and systems under suboptimum conditions (1). In these periods, the neuronal and endocrine systems undergo critical periods of growth and maturation. They also develop their interrelationship signaling pathways (2). Thus, there are irreversible metabolic consequences when the gestation and/or lactation is/are perturbed. Several experiments in animal models have shown that nutrition (3), hormone-regulated metabolism $(4,5)$, and other toxic influences such as thyroid disruptors affect metabolic and thyroid programming (6). In these conditions, adaptive metabolic strategies in the offspring change the metabolic set points in order to permit survival under critical conditions (7); for example, malnutrition in lactating rats was associated with changes in body weight $(3,8)$ and thyroid dysfunction in their adult offspring (9).

Congenital hypothyroidism is a clinical and biochemical disease caused by low mother-transferred fetus thyroid hormones during gestation (10); it compromises hypothalamus-pituitary-thyroid gland (HPT) axis development and functionality $(11,12)$. There is evidence that congenital hypothyroidism 
affects the offspring metabolic programming because it reduces growth hormone (13) and insulin-like growth factor binding protein (IGBFP)-2 responses (14). In addition, the wet nurse thyroid state is very important for the offspring metabolic and thyroid programming. It has been shown that thyroid hormones are necessary for preparing the breast for lactation (15) because they participate in the mammary gland lipolytic enzymes and proteases synthesis and expression. Thus, the milk of a hypothyroid wet nurse has low energetic metabolites, such as lipids and proteins $(16,17)$; moreover, it contains a low hormone concentration (i.e., thyroid hormone IGF-1, growth hormone and leptin), which altered the metabolic actions in the offspring $(17,18)$. In particular, thyroid hormones are important for the HPT development during the first ten days of lactation (19), and the adequate protein supply during lactation ensures the correct thyroid programming (20).

Altogether, congenital hypothyroidism causes metabolic programming changes. Further, the low quality of the milk produced by a hypothyroid wet nurse could modify thyroid gland programming. Therefore, the study aimed to prove that lactation in hypothyroid offspring with a euthyroid wet nurse, could improve hypothyroidism by causing metabolic and thyroid programming alteration.

\section{MATERIALS AND METHODS}

\section{Animals and experimental design}

All procedures were performed in accordance with the provisions of the laws and codes of Mexico in the seventh article of the General Health Law regarding health research (NOM-062-ZOO-2007). Additionally, the protocol was approved by the Internal Bioethical Committee (CEI-ENCB-021/2014).

Twenty female ten-week-old (250-280g) Wistar rats were used. The animals were housed in acrylic cages $(20 \times 30 \times 18 \mathrm{~cm})$ in a room with a light-dark cycle $(12: 12 \mathrm{~h})$ and controlled temperature $\left(2 \mathrm{l} \pm 1{ }^{\circ} \mathrm{C}\right)$; food and water were offered ad libitum. The rats were conditioned for a week before starting the experiment; they were randomly divided into two groups: euthyroid wet nurse (EWN, $\mathrm{n}=8$ ) and hypothyroid wet nurse $($ HWN, $\mathrm{n}=12)$. Thyroidectomy with parathyroid reimplantation was performed to the hypothyroid group. Thyroidectomy was carried out on rats anesthetized with ketamine $(10 \mathrm{mg} / \mathrm{kg}, \mathrm{im})$-xylazine $(5 \mathrm{mg} / \mathrm{kg}, \mathrm{im})$. The previously described method was used (21). Briefly, by using a stereomicroscope (Zeiss, Germany) for better observation, the sternothyroid muscle was cut and the trachea was exposed. The parathyroid gland was located, dissected from the thyroid gland, and reimplanted into the surrounding neck muscle. The thyroid gland was carefully dissected to avoid injury to the laryngeal nerve and was completely excised. After surgery, enrofloxacin $(10 \mathrm{mg} / \mathrm{kg}, \mathrm{im})$ and mefenamic acid ( $1 \mathrm{mg} / \mathrm{kg}$ ig) were administered over three days to alleviate pain and prevent infection. During surgery and in the recovery period, $0.05 \%$ of death was presented. Seven days post-surgery, three females were placed into a plastic cage with one male for mating. Only the thyroidectomized rats received pulses of $20 \mu \mathrm{g} / \mathrm{kg} \mathrm{sc} \mathrm{T}_{4}$ twice; first at the beginning of mating and, second, one day before labor; in previous experiments we found a low fertilization rate and a high delivery mortality rate of the HWN if these pulses of thyroid hormones were not administered. One day after birth, the pups were randomly assigned to groups (each group consisted of four males and four females raised by a wet nurse wet nurse) and were divided into three groups: euthyroid group (EO, $\mathrm{n}=12)$, hypothyroid group $(\mathrm{HO}$, $\mathrm{n}=12$ ) and hypothyroid replacement with euthyroid wet nurse (HRO, $n=12$ ). The HRO group consists of placing hypothyroid offspring with a euthyroid wet nurse.

\section{Metabolic evaluations}

\section{Energetic metabolites quantification in the nurses' millk}

The milk quality from each wet nurse in the different groups was tested. On day 7, 14 and 21 a dose of oxytocin $(0.2 \mathrm{UI} / \mathrm{kg}$ i.p.) was administered to make the milk ejection process faster, then 10 min after oxytocin administration the rats were lightly anesthetized with ether and the mammary gland was gently pressed to simulate stimulating suction; the milk was then collected into individual vials (16). During the process the offspring were separated from the wet nurse for a period of 10 minutes to avoid stress by maternal separation. We obtained $500 \mu \mathrm{L}$ stored at $-20^{\circ} \mathrm{C}$. Until use, the amount of proteins, triglycerides, lactate and non-esterified fatty acid (NEFA) were quantified by using a kit from Randox.

\section{Metabolic evaluations in offspring}

During the whole treatment (P56), we measured the body weight and length two times a week during lactation. From P21 to P56, body weight and energy intake were determined weekly. We evaluated the rats at P35 and P55 because those dates are associated with prepubertal and postpubertal ages. After six hours of 
fasting, at P35 and P56 blood samples from the tail vein were obtained and the serum was separated and stored at $-70{ }^{\circ} \mathrm{C}$ until assayed. Glucose, triglycerides, cholesterol and NEFA were measured. At P56, the animals were sacrificed by decapitation; the thyroid gland and mesenteric, retroperitoneal, epididymal or paraendometrial adipose tissue were dissected and were weighed immediately after removal.

\section{Thyroid programming in offspring}

\section{Determination of serum concentrations of $T_{3}$ and $T_{4}$}

We collected blood samples from the tail vein at 36 and 56 days post birth. For the determination of serum concentrations of $\mathrm{T}_{3}$ and $\mathrm{T}_{4}$ animals were not starved because the prolonged fast modifies the serum concentration of thyroid hormones. The samples were centrifuged at $3000 \mathrm{rpm}$ for $5 \mathrm{~min}$ to obtain serum for thyroid hormone determination. We used the IMMULITE 2000 System (Siemens) to determine free $\mathrm{T}_{3}$ (Calibration Range: 40 to $600 \mathrm{ng} / \mathrm{dL}$, Analytical Sensitivity: $19 \mathrm{ng} / \mathrm{dL}$ ) and $\mathrm{T}_{4}$ (Calibration Range: 1.0 $-24 \mu \mathrm{g} / \mathrm{dL}$, Analytical Sensitivity: $0.4 \mu \mathrm{g} / \mathrm{dL}$ ).

\section{Morphological analysis of the thyroid gland}

All animals were anesthetized at 56 days post birth with monosodium pentobarbital $(45 \mathrm{mg} / \mathrm{kg})$ after blood sampling. Six animals from each group underwent a total thyroidectomy using a stereoscopic microscope. We carefully preserved the thyroid gland lobes and the isthmus. The thyroid gland was immediately weighed on an analytical balance. Meanwhile, six animals from each group were used for histology. Briefly, $15 \mathrm{~mm}$ were dissected from the trachea containing the thyroid gland. It was fixed in $4 \%$ paraformaldehyde in PBS during $48 \mathrm{~h}$. After that, the organs were processed by the conventional paraffin embedding technique. Serial sections of $7 \mu \mathrm{m}$ were obtained and stained with hematoxylin-eosin.

\section{Statistical analysis}

All of the variables evaluated were given as the mean \pm standard error. The body weight, length, milk quantifications, clinical biochemistry of energetic metabolites and thyroid hormones were evaluated by repeated-measure two-way ANOVA and Student-Newman-Keuls post hoc. The two factors were age and thyroid state. The thyroid gland and adipose tissue weight were analyzed by one-way ANOVA and Student-Newman-Keuls post hoc. $\mathrm{P}<0.05$ was considered statistically significant.

\section{RESULTS}

In Table 1, we observed the wet nurses milk quality during lactation. It was shown that hypothyroid wet nurses have a lower concentration of proteins (16-26\%), triglycerides (22-29\%), lactate $(22-37 \%)$ and NEFA $(10-11 \%)$ in all days that were evaluated in comparison to the euthyroid wet nurses.

Figure 1 shows the hypothyroid metabolic effects on body weight (panel A and B), length (panel C and D) and energy intake (panel E and F). Perinatal and postnatal hypothyroidism reduces body weight gain, length and energy intake in male (body weight gain 23\%, length $13 \%$, energy intake $15 \%$ respect to AUC of EO) and female rats (body weight gain $33 \%$, length $11 \%$, energy intake $21 \%$ respect to AUC of EO). Meanwhile, the hypothyroid group with a euthyroid wet nurse has the same metabolic pattern as the hypothyroid group (male body weight gain $28 \%$, length $11 \%$, energy intake $11 \%$, female body weight gain $28 \%$, length $18 \%$, energy intake $15 \%$, respect to AUC of EO).

The clinical biochemistry of the energetic metabolites that were analyzed is shown in Table 2. The hypothyroid and hypothyroid with euthyroid wet nurse groups suggested increased glucose (12-25\%), triglycerides (47-67\%) and cholesterol (55-62\%) and reduced NEFA (17-28\%) in both ages and genders.

Figure 2 shows the reserves of adipose tissue on P56. We found that females in the HO and HRO groups reduced all reserves of adipose tissue (mesenteric $31 \%$, retroperitoneal $68 \%$, paraendometrial $67 \%$ for $\mathrm{HO}$ and mesenteric $21 \%$, retroperitoneal $59 \%$, paraendometrial $58 \%$ for $\mathrm{HRO}$ with respect to EO). Meanwhile, males of

Table 1. Milk quality evaluation during lactation

\begin{tabular}{lccc}
\hline \multirow{2}{*}{$\begin{array}{c}\text { Milk } \\
\text { energetic } \\
\text { metabolites }\end{array}$} & $\begin{array}{c}\text { Day } \\
\text { lactation }\end{array}$ & $\begin{array}{c}\text { Euthyroid } \\
\text { (EWN, } \mathbf{n}=\mathbf{8})\end{array}$ & $\begin{array}{c}\text { Hypothyroid } \\
\text { (HWN, } \mathbf{n}=\mathbf{1 2})\end{array}$ \\
\cline { 3 - 4 } Proteins & 7 & $53.23 \pm 0.81^{\mathrm{a}}$ & $45.04 \pm 1.14^{\mathrm{b}}$ \\
(mg/dL) & 14 & $59.08 \pm 1.48^{\mathrm{a}}$ & $43.91 \pm 0.984^{\mathrm{b}}$ \\
& 21 & $57.73 \pm 1.16^{\mathrm{a}}$ & $47.26 \pm 1.67^{\mathrm{a}}$ \\
Triglycerides & 7 & $163.06 \pm 7.95^{\mathrm{a}}$ & $128.33 \pm 6.53^{\mathrm{d}}$ \\
(mg/dL) & 14 & $155.24 \pm 9.59^{\mathrm{b}}$ & $110.14 \pm 7.63^{\mathrm{a}}$ \\
& 21 & $153.13 \pm 7.12^{\mathrm{c}}$ & $119.75 \pm 4.20^{\mathrm{c}}$ \\
Lactate & 7 & $7.90 \pm 0.38^{\mathrm{a}}$ & $6.13 \pm 0.55^{\mathrm{b}}$ \\
(mg/dL) & 14 & $6.93 \pm 0.57^{\mathrm{b}}$ & $4.38 \pm 0.475^{\mathrm{d}}$ \\
& 21 & $9.77 \pm 0.64^{\mathrm{c}}$ & $7.03 \pm 0.72^{\mathrm{e}}$ \\
NEFA & 7 & $14.12 \pm 0.79^{\mathrm{a}}$ & $12.73 \pm 0.65^{\mathrm{b}}$ \\
(mmol/mL) & 14 & $13.48 \pm 0.42^{\mathrm{a}}$ & $12.03 \pm 1.12^{\mathrm{b}}$ \\
& 21 & $14.92 \pm 0.39^{\mathrm{a}}$ & $12.66 \pm 1.54^{\mathrm{b}}$ \\
\hline
\end{tabular}

$(\mathrm{a} \neq \mathrm{b} \neq \mathrm{c} \neq \mathrm{d} \neq \mathrm{e} \neq \mathrm{f}) p<0.05$. RM two-way ANOVA and Student-Newman-Keuls post hoc. 

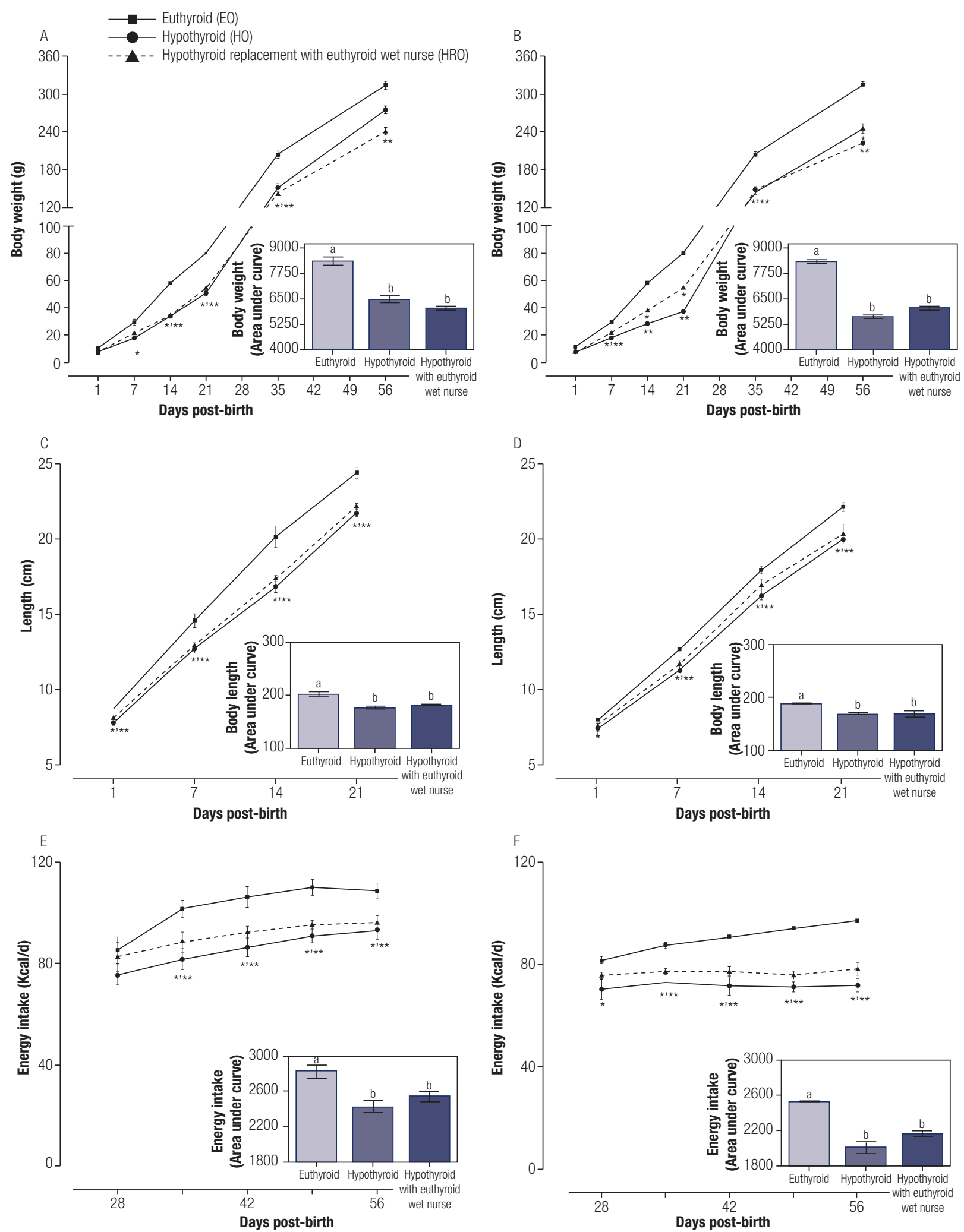

Figure 1. Effect of pre-natal and post-natal hypothyroid on body weight ( $A$ and $B$ ) and length ( $C$ and $D)$ and energy intake (E and $F)$ of male $(A, C$ and $E)$ and female $(B, D$ and $F)$ rats $(n=12)$. The data represent the mean \pm the standard error, the bar graphs of the sides represent the area under the curve of the graph. $\left(^{*}\right) p<0.05$ vs the euthyroid group; $\left(^{* *}\right)$ vs hypothyroid group at same day; $\mathrm{a} \neq \mathrm{b} p<0.05$. RM two-way ANOVA and Student Newman Keuls post hoc. 
Table 2. Effect of pre-natal and post-natal hypothyroidism in clinical biochemistry of energetic metabolites in males and females at the pre-pubertal and post-pubertal age

\begin{tabular}{|c|c|c|c|c|c|c|c|}
\hline & & & pubertal age ( $\mathrm{P3}$ & & & tpubertal age ( $\mathrm{P}$ & \\
\hline Serum & oncentration & Euthi & & & & & \\
\hline & Glucose (mg/dL) & $95.60 \pm 1.25^{\mathrm{a}}$ & $117.00 \pm 2.72^{b}$ & $110.60 \pm 4.65^{b}$ & $95.40 \pm 0.872^{\mathrm{a}}$ & $119.40 \pm 4.37^{\mathrm{b}}$ & $107.80 \pm 4.02^{b}$ \\
\hline & Triglycerides (mg/dL) & $78.80 \pm 3.61^{\mathrm{a}}$ & $120.00 \pm 6.74^{b}$ & $116.60 \pm 7.45^{b}$ & $79.00 \pm 3.78^{a}$ & $132.20 \pm 9.49^{b}$ & $130.60 \pm 7.22^{b}$ \\
\hline & Cholesterol (mg/dL) & $50.00 \pm 1.92^{\mathrm{a}}$ & $80.00 \pm 2.45^{b}$ & $77.60 \pm 2.79^{b}$ & $56.80 \pm 3.18^{a}$ & $91.60 \pm 3.59^{b}$ & $89.80 \pm 1.50^{b}$ \\
\hline & $\mathrm{NEFA}(\mathrm{mmol} / \mathrm{mL})$ & $1.36 \pm 0.07^{\mathrm{a}}$ & $1.08 \pm 0.06^{b}$ & $0.98 \pm 0.05^{b}$ & $1.74 \pm 0.11^{\mathrm{a}}$ & $0.96 \pm 0.05^{b}$ & $0.96 \pm 0.19^{b}$ \\
\hline & Glucose (mg/dL) & $95.20 \pm 1.16^{a}$ & $114.80 \pm 4.26^{b}$ & $104.80 \pm 4.64^{b}$ & $94.40 \pm 1.81^{\mathrm{a}}$ & $112.80 \pm 6.65^{b}$ & $108.00 \pm 4.50^{b}$ \\
\hline & Triglycerides (mg/dL) & $85.60 \pm 4.23^{\mathrm{a}}$ & $117.20 \pm 7.46^{b}$ & $128.40 \pm 9.96^{b}$ & $87.80 \pm 3.15^{\mathrm{a}}$ & $130.40 \pm 9.84^{b}$ & $133.00 \pm 10.38^{b}$ \\
\hline . & Cholesterol (mg/dL) & $57.20 \pm 3.41^{\mathrm{a}}$ & $88.00 \pm 3.44^{b}$ & $86.20 \pm 3.31^{b}$ & $57.40 \pm 2.23^{a}$ & $90.80 \pm 2.52^{b}$ & $89.40 \pm 1.47^{b}$ \\
\hline & $\mathrm{NEFA}(\mathrm{mmol} / \mathrm{mL})$ & $1.34 \pm 0.06^{\mathrm{a}}$ & $1.15 \pm 0.06^{b}$ & $1.01 \pm 0.05^{b}$ & $1.65 \pm 0.09^{\mathrm{a}}$ & $0.88 \pm 0.06^{b}$ & $0.83 \pm 0.14^{b}$ \\
\hline
\end{tabular}

$(\mathrm{a} \neq \mathrm{b}) p<0.05$. RM two-way ANOVA and Student-Newman-Keuls post hoc.
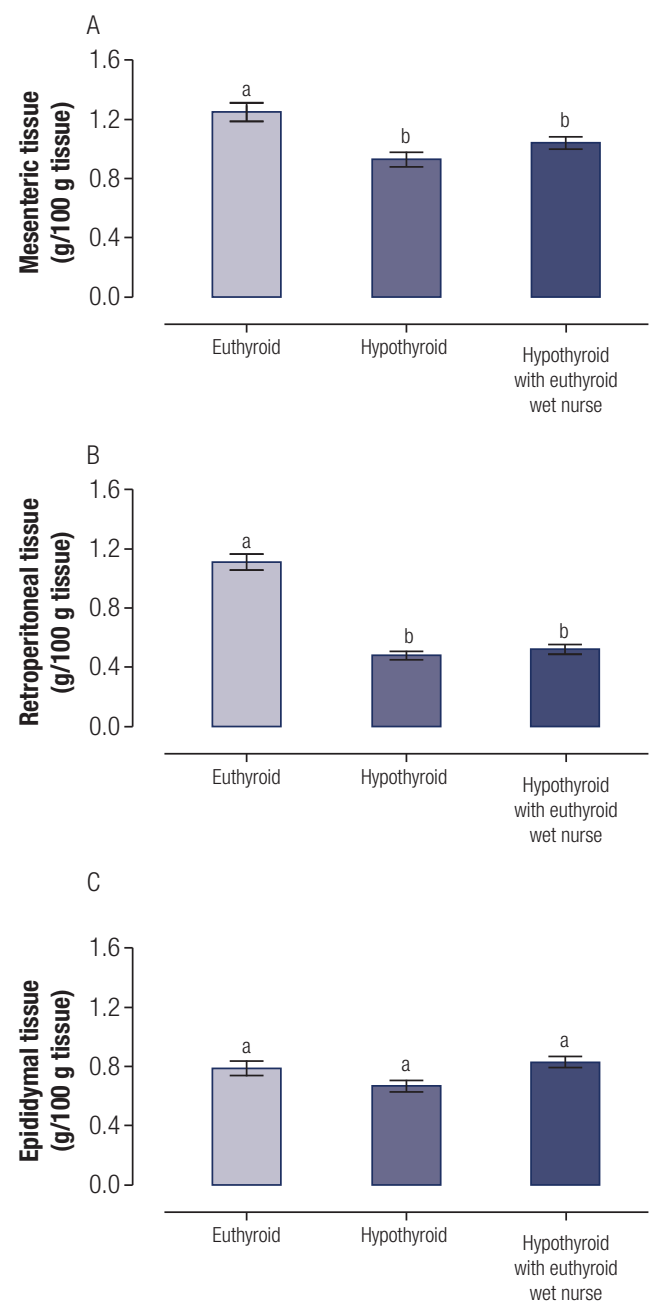
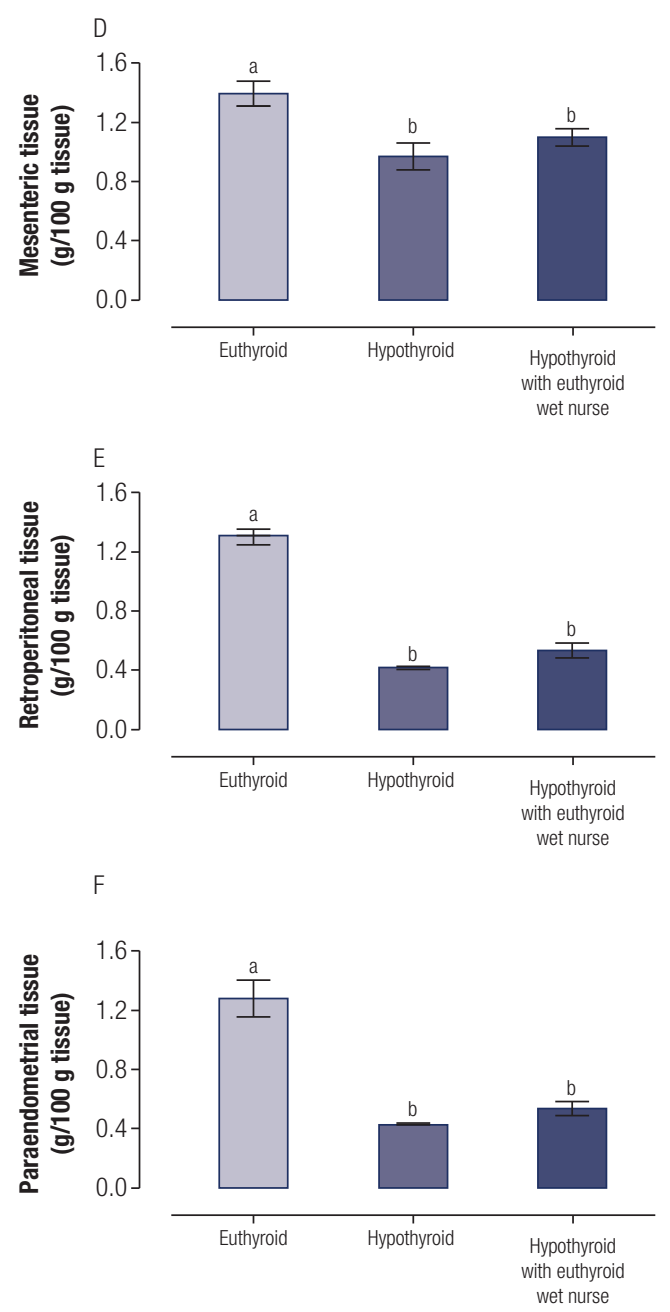

Figure 2. Effect of pre-natal and post-natal hypothyroidism on reserves adipose tissue quantification of males $[(A)$ mesenteric, $(B)$ retroperitoneal, (C) epididymal] and females [(D) mesenteric, (E) retroperitoneal, (F) paraendometrial] $(n=12)$. $\left(^{*}\right) p<0.05$ vs the euthyroid group; $a \neq b p<0.05$. RM oneway ANOVA and Student Newmann Keuls post hoc. 
the same groups reduced only mesenteric ( $26 \%$ for HO and $17 \%$ for $\mathrm{HRO}$ respect to $\mathrm{EO})$ and retroperitoneal ( $57 \%$ for $\mathrm{HO}$ and $53 \%$ for $\mathrm{HRO}$ respect to $\mathrm{EO}$ ) adipose tissue.

The thyroid hormone concentrations and thyroid weight glands are shown in Table 3. It was observed that pre-natal and post-natal hypothyroidism caused a reduction on $\mathrm{T}_{3}$ and $\mathrm{T}_{4}$ at $\mathrm{P} 35$ (male reductions: $\mathrm{T}_{3}$ $19 \%$ and $\mathrm{T}_{4} 20 \%$; female reductions: $\mathrm{T}_{3} 22 \%$ and $\mathrm{T}_{4}$ $18 \%$ ) and P56 (male reductions: $\mathrm{T}_{3} 22 \%$ and $\mathrm{T}_{4} 34 \%$; female reductions: $\mathrm{T}_{3} 22 \%$ and $\mathrm{T}_{4} 25 \%$ ) in both genders. However, the hypothyroid group that had a euthyroid wet nurse presented a lower thyroid hormone reduction than the hypothyroid group at P35 (male reduction: $\mathrm{T}_{3} 3 \%$ and $\mathrm{T}_{4} 8 \%$; female reduction: $\mathrm{T}_{3} 7 \%$ and $\mathrm{T}_{4} 6 \%$ ) and P56 (male reduction: $\mathrm{T}_{3} 14 \%$ and $\mathrm{T}_{4} 19 \%$; female reduction: $\mathrm{T}_{3} 11 \%$ and $\mathrm{T}_{4} 7 \%$ ). Also, males and females of the hypothyroid group had a lower weight of the thyroid gland (34\% for males and $25 \%$ for females).

The arrows in Figure 3 show in the male (A) and female group (D) of EO, the thyroid gland has hemispherical follicles with follicular proper organization, abundant colloid and reabsorption lacunae are observed. In the male (B) and female (E) of $\mathrm{HO}$, the gland has the presence of larger follicles without the hemispherical characteristic shape with little colloid; in addition, central areas with follicular disorganization were observed. With respect to the HRO male $(\mathrm{C})$ and female $(\mathrm{F})$ groups, the follicles have hemispherical morphology, presenting abundant larger follicles without colloid and flat cells, as well as areas with follicular disorganization.

\section{DISCUSSION}

Lactation is a critical period because important cognitive and metabolic events occur (22). Adverse changes in the environment, such as malnutrition and abnormal weight-regulatory hormonal concentration in lactating rats, are associated with metabolic disease in adulthood (23). Thyroid hormones $(\mathrm{TH})$ are important in the mammary gland function because they participate in the adequate initiation and progress of lactation (15). In addition, the $\mathrm{TH}$ regulates energetic metabolic pathways as carbohydrates, lipids and proteins. Thus, the thyroid state in the wet nurses modifies the milk quality and the metabolic programming in the offspring (17). However, research has not yet determined whether the metabolic and thyroid programming alterations in hypothyroid offspring ( $\mathrm{HO})$ are the result of low nutritional intake of proteins and lipids and/or the low thyroid hormone contribution from the wet nurse during lactation. Thus, the aim of this study was to determine if hypothyroid offspring replacement with euthyroid wet nurses (HRO) during lactation develops thyroid and metabolic programming alterations during pre-pubertal and post-pubertal ages.

We observed that hypothyroid wet nurses (HWN) produce milk with lower energetic metabolites (proteins and lipids) than that of euthyroid wet nurses (EWN). Hypothyroidism affects mammary function and lactation because it reduces the activity and expression of enzymes involved in energetic metabolic pathways as lipogenesis, lipolytic and protein synthesis. Thus, the HWN compromise the offspring nutritional state by causing nutrient restriction during lactation and

Table 3. Effect of pre-natal and post-natal hypothyroidism on serum thyroid hormones quantification and the thyroid gland weight of males and females at the pre-pubertal and post-pubertal age

\begin{tabular}{|c|c|c|c|c|c|c|c|}
\hline & & & pubertal age ( $P$ & & & pubertal age ( $P$ & \\
\hline Serum & oncentration & Euthyroid & Hypothyroid & $\begin{array}{l}\text { Hypothyroid } \\
\text { with Euthyroid }\end{array}$ & Euthyroid & Hypothyroid & $\begin{array}{c}\text { Hypothyroid } \\
\text { with Euthyroid }\end{array}$ \\
\hline$M$ & $T_{3}(n g / d L)(n=12)$ & $104.34 \pm 5.37^{a}$ & $83.78 \pm 3.89^{b}$ & $96.46 \pm 1.68^{c}$ & $126.80 \pm 4.62^{\mathrm{a}}$ & $84.58 \pm 3.83^{b}$ & $103.02 \pm 2.26^{c}$ \\
\hline & $T_{4}(\mu \mathrm{g} / \mathrm{dL})(n=12)$ & $9.20 \pm 0.14^{a}$ & $7.50 \pm 0.08^{b}$ & $8.96 \pm 0.20^{c}$ & $10.92 \pm 0.22^{\mathrm{a}}$ & $8.58 \pm 0.27^{b}$ & $9.40 \pm 0.12^{c}$ \\
\hline & $\begin{array}{l}\text { Thyroid gland weight } \\
(\mathrm{mg})(\mathrm{n}=6)\end{array}$ & ----- & ----- & ----- & $18.20 \pm 1.21^{\mathrm{a}}$ & $12.10 \pm 0.48^{b}$ & $14.94 \pm 1.146^{c}$ \\
\hline & $T_{3}(n g / d L)(n=12)$ & $88.66 \pm 2.69^{a}$ & $73.36 \pm 2.18^{b}$ & $94.34 \pm 2.61^{c}$ & $124.26 \pm 8.96^{a}$ & $94.16 \pm 5.22^{b}$ & $90.78 \pm 2.52^{c}$ \\
\hline remare & $T_{4}(\mu \mathrm{g} / \mathrm{dL})(n=12)$ & $10.22 \pm 0.21^{a}$ & $7.98 \pm 0.26^{b}$ & $9.54 \pm 0.16^{c}$ & $10.60 \pm 0.22^{\mathrm{a}}$ & $8.32 \pm 0.19^{b}$ & $9.00 \pm 0.17^{c}$ \\
\hline & $\begin{array}{l}\text { Thyroid gland weight } \\
(\mathrm{mg})(\mathrm{n}=6)\end{array}$ & ----- & ----- & ----- & $17.2 \pm 1.02^{\mathrm{a}}$ & $12.94 \pm 0.37^{b}$ & $15.92 \pm 0.36^{c}$ \\
\hline
\end{tabular}

$(a \neq b \neq c) p<0.05$. RM two-way ANOVA and Student-Newman-Keuls post hoc. (---- not evaluated). 
metabolic readjustment (24). We observed that $\mathrm{HO}$ has metabolic alterations and thyroid dysfunction in females and males. There are hormonal inputs that are related to the metabolic programming such as glucocorticoid, insulin and leptin (25). However, in recent years the relationship between $\mathrm{TH}$ and metabolic programming has been studied because TH can probably participate in metabolic programming during critical stages of development (26).
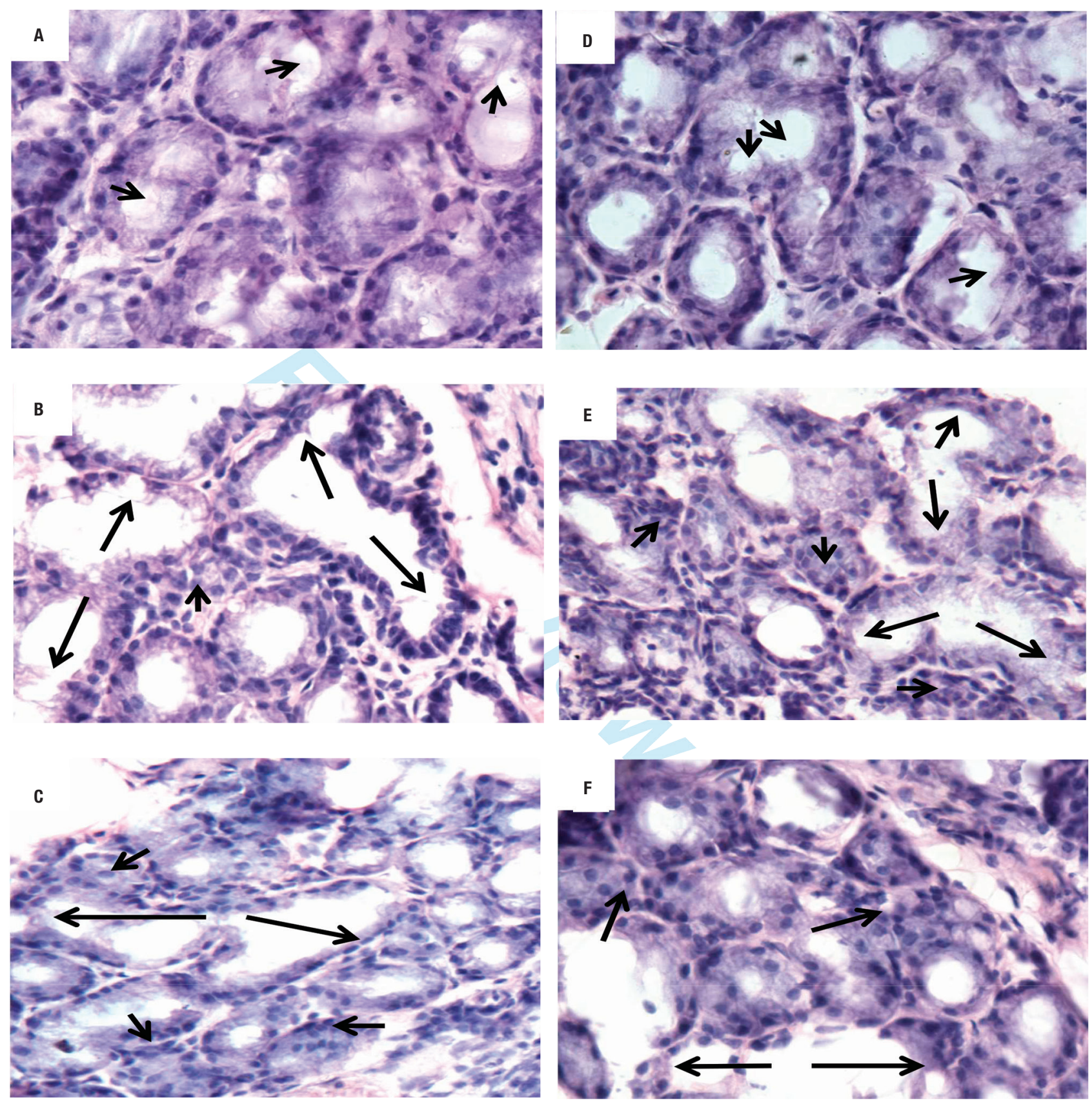

Figure 3. Effect of pre-natal and post-natal hypothyroidism on thyroid gland cytoarchitecture. The photomicrographs show histological cuts with HE stain. Euthyroid males (A) and females (D); hypothyroid males (B) and females (E); hypothyroid replacement with euthyroid wet nurse males (C) and females (F). Arrows show the follicular organization, colloid and reabsorption lacunae. 
process of puberty and the presence of metabolic and thyroid disorders that are exacerbated in the long term (28). Even though the mechanism of this effect is still unknown, metabolic programming may be affected permanently by an imbalance in the $\mathrm{TH}$ supply during fetal life as it occurs in congenital hypothyroidism and causes long-term changes in the offspring. It has been observed that congenital hypothyroidism decreased insulin secretion in adulthood $(29,30)$, which is related to high glucose concentration (31). In addition, lactation is an important period in which the correct metabolic and thyroid programming is established (23). It is possible that, by restoring lactation on $\mathrm{HO}$, metabolic and thyroid programming could be improved. To analyze it, we employed the HRO to restore the hormonal and nutrimental supply during lactation. It has been shown that cross fostering during the first postnatal days can be an effective method to improve the newborn nutritional status in some species such as pigs (32). However, in rats, cross fostering is usually used to study behavior and thyroid disruptors in relationship with some metabolic parameters (33). So, this is the first study to use cross fostering in rats during lactation through the HRO with a EWN. However, this methodological strategy does not prevent metabolic programming; nevertheless, the thyroid programming was mildly improved. It has been observed that HWN reduces IGF-I and TH concentration in the milk. Thus, the metabolic restoration during lactation with EWN through quality milk provides the correct milk metabolic hormones concentration, but it does not prevent hypothyroidism. On other hand, the euthyroid milk provides more energetic metabolites, such as lipid and proteins, than hypothyroid milk (17). Perhaps the metabolic programming was not improved in HRO because the congenital hypothyroidism causes metabolic programming alteration. Furthermore, regarding thyroid programming, in the HRO, thyroid gland dysfunction was partially prevented. It has been observed that maternal TH during the end of gestation and throughout the ten lactation days programmed the HPT in the offspring (19,34). In addition, the nutritional supply during lactation it is important for the normal thyroid function (3). Thus, in our model, when the HO was fed with the euthyroid milk, the energetic metabolites and the thyroid hormone improve the HPT axis.

In conclusion, we suggest that the thyroid status of the mother during gestation stage is very important for the correct metabolic programming in the offspring.
Moreover, lactation plays an important role in thyroid programming.

Acknowledgements: this study was partially supported by CONACyT (221057) and SIP-IPN (20171416; 20171284). We thank Instituto Politécnico Nacional and CONACyT for financial support. The researchers are fellows of EDI, COFAA and SNI.

Disclosure: no potential conflict of interest relevant to this article was reported.

\section{REFERENCES}

1. Fowden AL, Forhead AJ. Endocrine mechanisms of intrauterine programming. Reproduction. 2004;127(5):515-26.

2. Fernandez-Twinn DS, Ozanne SE. Mechanisms by which poor early growth programs type-2 diabetes, obesity and the metabolic syndrome. Physiol Behav. 2006;88(3):234-43.

3. Ayala-Moreno R, Racotta R, Anguiano B, Aceves C, Quevedo L. Perinatal undernutrition programmes thyroid function in the adult rat offspring. Br J Nutr. 2013;110(12):2207-15.

4. Ozdemir H, Akman I, Coskun S, Demirel U, Turan S, Bereket A, et al. Maternal thyroid dysfunction and neonatal thyroid problems. Int J Endocrinol. 2013;2013:987843.

5. ZahediasI S. Importance of thyroid hormones in intrauterine programming. 2010;8(4):186-7.

6. Wilcoxon JS, Redei EE. Prenatal programming of adult thyroid function by alcohol and thyroid hormones. Am J Physiol Endocrinol Metab. 2004;287(2):E318-26.

7. Patel MS, Srinivasan M, Laychock SG. Metabolic programming: Role of nutrition in the immediate postnatal life. J Inherit Metab Dis. 2009;32(2):218-28.

8. Passos MCF, Ramos CF, Moura EG. Short and long term effects of malnutrition in rats during lactation on the body weight of offspring. Nutr Res. 2000;20(11):1603-12.

9. Passos MC, da Fonte Ramos C, Dutra SC, Mouço T de ME. Longterm effects of malnutrition during lactation on the thyroid function of offspring. Horm Metab Res. 2002;34(1):40-3.

10. Jain V, Agarwal R, Deorari AK, PaulVK. Congenital hypothyroidism. Indian J Pediatr. 2008 Apr;75(4):363-7.

11. Obregon M, Calvo R, Escobar Del Rey F, Morreale De Escobar G. Ontogenesis of thyroid function and interactions with maternal function. Endocr Dev. 2007;10:86-98.

12. Patel J, Landers K, Li H, Mortimer RH, Richard K. Delivery of maternal thyroid hormones to the fetus. Trends Endocrinol Metab. 2011;22(5):164-70.

13. Seo H, Wunderlich C, Vassart G, Refetoff S. Growth hormone responses to thyroid hormone in the neonatal rat. Resistance and anamnestic response. J Clin Invest. 1981;67(2):569-74.

14. Ramos S, Goya L, Martin MA, Escrivá F, Pascual-Leone AM. Influence of hypothyroidism on circulating concentrations and liver expression of IGF-binding proteins mRNA from neonatal and adult rats. J Endocrinol. 2002;172(2):363-73.

15. Campo Verde Arboccó F, Sasso CV, Nasif DL, Hapon MB, Jahn G. Effect of hypothyroidism on the expression of nuclear receptors and their co-regulators in mammary gland during lactation in the rat. Mol Cell Endocrinol. 2015;412:26-35.

16. Hapon MB, Varas SM, Giménez MS, Jahn GA. Reduction of Mammary and Liver Lipogenesis and Alteration of Milk Composition during Lactation in Rats by Hypothyroidism. Thyroid. 2007;17(1):11-8.

17. Hapon MB, Simoncini M, Via G, Jahn GA. Effect of hypothyroidism on hormone profiles in virgin, pregnant and lactating rats, and on lactation. Reproduction. 2003;126(3):371-82. 
18. Passos MCF, Lisboa PC, Pereira-Toste F, Oliveira E, Moura EG. Developmental plasticity in thyroid function primed by maternal hyperleptinemia in early lactation: a time-course study in rats. Horm Metab Res. 2012;44(7):520-6.

19. Brown RS, Shalhoub V, Coulter S, Alex S, Joris I, De Vito W, et al. Developmental regulation of thyrotropin receptor gene expression in the fetal and neonatal rat thyroid: relation to thyroid morphology and to thyroid-specific gene expression. Endocrinology. 2000;141(1):340-5.

20. Ramos CF, Lima APS, Teixeira CV, Brito PD, Moura EG. Thyroid function in post-weaning rats whose dams were fed a low-protein diet during suckling. Brazilian J Med Biol Res. 1997;30(1):133-7.

21. Pineda-Reynoso M, Cano-Europa E, Blas-Valdivia V, HernandezGarcia A, Franco-Colin M, Ortiz-Butron R. Hypothyroidism during neonatal and perinatal period induced by thyroidectomy of the mother causes depressive-like behavior in prepubertal rats. Neuropsychiatr Dis Treat. 2010;6:137-43.

22. Rodrigues AL, de Moura EG, Fonseca Passos MC, Potente Dutra SC, Lisboa PC. Postnatal early overnutrition changes the leptin signalling pathway in the hypothalamic-pituitary-thyroid axis of young and adult rats. J Physiol. 2009;587(11):2647-61.

23. Patel MS, Srinivasan M. Metabolic programming in the immediate postnatal life. Ann Nutr Metab. 2011 Jan [cited 2014 May 4];58 Suppl 2(suppl 2):18-28.

24. Hapon MB, Varas SM, Jahn GA, Gimenez MS. Effects of hypothyroidism on mammary and liver lipid metabolism in virgin and late-pregnant rats. J Lipid Res. 2005;46(6):1320-30.

25. Fowden $A L$, Forhead AJ. Hormones as epigenetic signals in developmental programming. Exp Physiol. 2009;94(6):607-25.

26. Bagheripuor F, Ghanbari M. Comparison of the effects of fetal hypothyroidism on glucose tolerance in male and female rat offspring. 2015;(24):179-85.
27. Castellano JM, Bentsen AH, Sánchez-Garrido MA, Ruiz-Pino F, Romero M, Garcia-Galiano D, et al. Early metabolic programming of puberty onset: Impact of changes in postnatal feeding and rearing conditions on the timing of puberty and development of the hypothalamic kisspeptin system. Endocrinology. 2011;152(9):3396-408.

28. Engelbregt MJ, Houdijk ME, Popp-Snijders C, Delemarre-van de Waal HA. The effects of intra-uterine growth retardation and postnatal undernutrition on onset of puberty in male and female rats. Pediatr Res. 2000;48(6):803-7.

29. Farahani $H$, Ghasemi $A$, Roghani MZS. The effect of maternal hypothyroidism on the carbohydrate metabolism and insulin secretion of isolated islets in adult male offspring of rats. Horm Metab Res. 2010:42:792-7.

30. Karbalaei N, Ghasemi A, Hedayati M, Godini AZS. The possible mechanisms by which maternal hypothyroidism impairs insulin secretion in adult male offspring in rats. Exp Physiol. 2014;99(4):701-14

31. Karbalaei N, Ghasemi A, Faraji FZS. Comparison of the effect of maternal hypothyroidism on carbohydrate metabolism in young and aged male offspring in rats. Scand J Clin Lab Invest. 2013;73:87-94

32. Deen MGH, Bilkei G. Cross fostering of low-birthweight piglets. Livest Prod Sci. 2004;90(2-3):279-84.

33. Crofton KM. PCBs, Thyroid Hormones, and Ototoxicity in Rats: Cross-Fostering Experiments Demonstrate the Impact of Postnatal Lactation Exposure. Toxicol Sci. 2000;57(1):131-40.

34. Calvo R, Obregón MJ, Ruiz de Oña C, Escobar del Rey F, Morreale de Escobar G. Congenital hypothyroidism, as studied in rats. Crucial role of maternal thyroxine but not of 3,5,3'-triiodothyronine in the protection of the fetal brain. J Clin Invest. 1990;86(3): 889-99. 